\title{
Europe and the Transformation of French Policy-Making: a Cross-Sectoral Approach
}

\author{
by Richard Balme and Cornelia Woll
}

\begin{abstract}
This article sheds light on the "Europeanisation" of French policy-making - defined as the national adjustment to European integration - and asks whether different policy domains experience the same kind of pressure to adjust. Four sectors representing different policy types are examined: monetary and budgetary policies, public services, agricultural policy and equal employment. This cross-sectional approach reveals different degrees of change and patterns of adaptation, whilst in no case the EU fully supplanted national decision-making. The authors' conclusion suggests that regulative and redistributive policies are less conflicting with European integration than distributive policies at the core of the French welfare state, but that the latter are also strongly resilient and resistant to radical changes. Patterns of policy changes are highly complex and diversified, and their "path-dependency" is rooted in the political feasibility of public policy at the domestic level.
\end{abstract}

Der Beitrag analysiert die „Europäisierung“ zentraler Politikbereiche in Frankreich, wobei vier Felder im Zentrum stehen: die Geld- und Haushaltspolitik, öffentliche Dienstleistungen, die Agrarpolitik sowie arbeitsrechtliche Gleichstellungspolitiken. In der vergleichenden Untersuchung wird deutlich, dass sowohl die Reichweite des Wandels als auch die Muster der Anpassung unterschiedlich ausgeprägt sind; in keinem Fall finden sich Entscheidungsprozesse vollständig „europäisiert“. Regulative und redistributive Politiken erscheinen in Bezug auf die europäische Integration weniger problematisch als der distributive Kern des französischen Wohlfahrtsstaates, letzterer ist aber grundlegenden Veränderungen gegenüber sehr viel widerstandsfähiger. Europäisierung ist also nicht gleichbedeutend mit einer alleinigen Ausrichtung der Politik an regulativen Leitbildern. Der Wandel verläuft vielmehr nach äußerst komplexen Mustern und ist mit Blick auf die unterschiedliche nationale Umsetzbarkeit in hohem Maße "pfadabhängig“.

\section{Introduction}

Although the recent Europeanisation debate has so far reached few common conclusions, there is at least a sense that something important has changed within member states in response to European integration. ${ }^{1}$ Especially during the last

1 See Featherstone, K./Radaelli, C. (eds.): The Politics of Europeanization, Oxford, 2003. 
two decades, changes in traditional policy-making became more and more visible. As a model of state-centred policy-making, the French political system has drawn considerable attention from scholars interested in these transformations. ${ }^{2}$ Indeed, it may be thought that the Jacobean tradition of centralised, hierarchical public action should be more resistant to the regulatory policy styles of the European Union (EU) than other more market-oriented policy traditions.

The investigation of this question has motivated the following analysis: How is French policy-making evolving under the influence of European integration? Even if most observers agree that such an adjustment process is happening, few go as far as to draw general conclusions. Europeanisation studies have either attempted at large theory-building ${ }^{3}$, or have focused on one particular dimension of the political system ${ }^{4}$. Only few authors have tried to analyse the adjustment process in different areas of policy-making in one or several member states. ${ }^{5}$ After briefly reviewing the structural adaptations of core elements within the French political system, this article proposes a more targeted investigation: How did this general transformation of policy-making in France affect policy processes and outputs in different issue areas?

Research on EU public policies and their implementation at the national level generally notes a re-orientation towards more regulatory policy-making within

2 Ladrech, R.: Europeanization of Domestic Politics and Institutions: the Case of France, in: Journal of Common Market Studies, 32/1 (1994), 69-88; Cole, A./Drake, H.: The Europeanization of the French Polity: Continuity, Change and Adaptation, in: Journal of European Public Policy, 7/1 (2000), 26-43; Guyomarch, A.: The Europeanization of Policy-Making, in: idem et al. (eds.): Developments in French Politics 2, London, 2001, 116-135.

3 Knill, C./Lehmkuhl, D.: How Europe Matters: Different Mechanisms of Europeanization, in: European Integration Online Papers, 3/7 (1999); Börzel, T. A./Risse, T.: When Europe Hits Home: Europeanization and Domestic Change, in: European Integration Online Papers, 4/15 (2000); Caporaso, J./Cowles, M. G./ Risse, T.: Transforming Europe, Ithaca, N. Y., 2001.

4 Tarrow, S.: The Europeanisation of Conflict: Reflections from a Social Movement Perspective, in: West European Politics, 18/2 (1995), 223-251; Falkner, G.: Corporatist Patterns of Decision-Making and Europeanisation: No Future in the Multi-Level Game?, in: European Integration Online Papers, 1/11 (1996); Muller, P.: L'Europeanization des Politiques Publiques, in: Politiques et Management Public, 15/1 (1997), $1-5$.

5 But see Töller, A. E.: The Europeanization of Public Policies - Understanding Idiosyncratic Mechanisms and Contigent Results, in: European Integration online Papers, 8/9 (2004); Radaelli, C.: The Europeanization of Public Policy, in: Featherstone, K./Radaelli C. (eds.), op. cit, 27-55. For policy-making in France, see Dubouis, L.: France, in: Rideau, J. (ed.): Les Etats membres de l'Union européenne: adaptation, mutations, résistances, Paris, 1997, 215-237; Guyomarch, A./Machin, H./Ritchie, E. (eds.): France in the European Union, London, 1998; Gueldry, M. R.: France and European Integration: Toward a Transnational Polity?, Westport, Ct., 2001; Szukala, A.: France: the European Transformation of the French Model, in: Wessels, W./Maurer, A./Mittag, J. (eds.): Fifteen Into One? The European Union and its Member States, Manchester, 2003, 216-247. 
Europe. ${ }^{6}$ Can one argue more generally that this tendency towards regulation replaced the traditional, state-centred French policy style? Analysing four casestudies - macro-economic policy-making, public services, agricultural policy and equal employment policy -, our investigation presents a more nuanced picture. Certainly, the trend towards regulatory solutions does characterise the changed policy fashion, in France as much as in other European countries. But in most policy areas, challenges to French policy-making have not led to a significant retreat of the state. ${ }^{7}$ Instead, a country-specific response managed to preserve a high degree of state intervention while allowing policies to evolve in coherence with European or international requirements. Vivien Schmidt has termed this particular French response "market-oriented dirigisme". ${ }^{8}$ Our policy studies, furthermore, show that European integration should not only be construed exclusively as pressures coming from "above". In many instances, French political leaders significantly contributed to the direction of policy evolution at the European level, or selectively applied those EU constraints that suited them most. As a consequence, the re-orientation of public policy in response to European integration is largely interpreted through national concepts and tailored to domestic political constraints, and often maintains a distinctively "French flavour".

\section{Studying Public Policy Change in France}

\section{Policy-making and Europeanisation}

In order to understand changes in policy-making, it is first necessary to distinguish between policy sectors and policy types. The impact of European integration obviously varies according to different sectors, following the EU institutions' competencies as defined by the European Treaties. Beyond legal provisions, the objectives, instruments and organisational features of different policy sectors are also likely to affect the degree and pattern of Europeanisation. This is what we refer to as policy "types". For his analysis of policy change, Giandomenico Majone

6 Majone, G.: Regulating Europe, London, 1996; idem: From the Positive to the Regulatory State: Causes and Consequences of Changes in the Mode of Governance, in: Journal of Public Policy, 17/2 (2003), 139167; Jobert, B.: Le retour tâtonnant de l'Etat, in: d'Arcy, F./Rouban, L. (eds.): De la Ve République à l'Europe, Paris, 1996, 315-327.

7 To the noticeable exception of industrial policy.

8 Schmidt, V.A.: Running on Empty: The End of Dirigisme in French Economic Leadership, in: Modern and Contemporary France, 5/2 (1997), 229-241, here 236. 
considered "macro-economic stabilisation, income redistribution, and market regulation" ${ }^{9}$ as three distinct categories of public policy. We try to be somewhat more specific by including Theodore Lowi's distinction between distributive and redistributive policies. ${ }^{10}$ Distributive policies use the state's resources to provide universal access to basic needs for the whole of society, such as public schools, public health, public transports or roads. Redistributive policies, such as subsidies to specific economic sectors, people living under the poverty threshold or the unemployed, by contrast aim at helping a particular segment of society. In order to cover a larger variety of policy areas, it is, furthermore, useful to replace $\mathrm{Ma}$ jone's narrowly defined "market regulation", which concentrates on the correction of market failures only, by regulation in Lowi's sense, which includes all policies aiming at controlling the conditions, results, standards or procedures of economic production. Such controls might aim at correcting market failures, but they can also serve other societal values, such as environmental protection or the inclusion of minorities in the workplace.

This leads to four policy types: macro-economic stabilisation, distributive policies, redistributive policies and regulative policies. Although most issue areas are characterised by a mix of different instruments, this classification helps to analyse which policy tools are favoured or questioned through Europeanisation, and to describe policy changes. The four areas examined below are representative of the four categories: a first part refers to monetary and budgetary policies as an example of macro-economic stabilisation; a second analyses the distributive provision of public services; a third looks at agricultural policy as a case of redistributive policies, and a final section studies the regulative policy of equal employment.

Some clarifications are also necessary about the concept of Europeanisation. So far, there is little common ground on either a definition or the mechanisms it tries to describe. ${ }^{11}$ For the purpose of this article, we define Europeanisation as the process through which domestic politics and policy-making of member states adjust to European integration..$^{12}$ Scholars studying Europeanisation acknowledge that it is very difficult to identify direct causal links between the EU and specific changes in domestic policy-making. As it is not possible to control for

9 Majone, G.: Regulating Europe, op. cit.

10 Lowi, T.: Four Systems of Policy, Politics and Choice, in: Public Administration Review, 32/4 (1972), 298310.

11 Olsen, J. P.: The Many Faces of Europeanization, Oslo, ARENA Working Papers, 02/2002; Radaelli, C.: The Europeanization of Public Policy, in: Featherstone, K./Radaelli, C. (eds.), op. cit., 27-56.

12 Eising, R.: Europäisierung und Integration - Konzepte in der EU Forschung, in: Jachtenfuchs, M./KohlerKoch, B. (eds.): Europäische Integration, Opladen, 2003, 387-416. 
European integration (i.e. to construct a case where French policy would evolve in the absence of EU policy-making), any observed change will always happen in a context of other developments, such as the globalisation of financial markets, the growth of international institutions or the change of the bipolar world order after the Cold War. We try to distinguish between these influences by concentrating on political developments specific to the integration process. Nonetheless, it is not claimed that all changes being described are the exclusive and direct effect of European integration.

\section{The Changing Structure of the Policy Process}

Over the years, European integration has become a day-to-day aspect of French politics, and, therefore, the list of related institutional changes is quite long. Since these multifaceted transformations tend to obscure a discussion about the most fundamental changes in the French political system, it is useful to start by providing an overview of the core elements that have been transformed. First, we can depict a normalisation and routinisation of European affairs in all aspects of the French political system, be they formal institutions, party cleavages or public opinion. Second, the impact of European integration on France is clearly concentrated in time. The activities around the single market project arguably rang in an identifiable period of intense "Europeanisation" starting in the mid-1980s.

We have analysed elsewhere the structural dimensions framing the decisionmaking process: the constitutional and legal basis, government organisation, the party system, the political mobilisation of non-governmental actors and, finally, public opinion. ${ }^{13}$ A common feature within all dimensions is a "normalisation" of European affairs in French policy-making. Legal adaptation, quite slow in the beginning, has become more effective during the last two decades. The government has reorganised to accommodate European decision-making, increasing the Prime Minister's influence on European affairs and easing the Parliament's participation. More generally speaking, the hierarchical, vertical structure of governmental decision-making has developed into a more effective, task-oriented management of European issues. The impacts of European integration on the party system and the organisation of social movements seemed more limited for a long time. However, a convergence of the dominant policy positions within major parties and non-governmental actors was coupled with radicalisation at the extreme

13 Balme, R./Woll, C.: France: Between Integration and National Sovereignty, in: Bulmer, S./Lequesne, C. (eds.): Member States and the European Union, Oxford, 2005, 97-118. 
ends of the spectrum. New cleavages emerged between established actors (both governmental and non-governmental) and more radical protest movements contesting the system as a whole. Such a cleavage also affected public opinion. While the majority of French citizens supported European integration for a long time, more radical views have turned into mainstream opinion during the debates preceding the constitutional referendum in May 2005.

Without major breakdown, a series of gradual changes associated with European integration deeply transformed the French political system. Incrementally, the structure of domestic policy-making was influenced by European integration. We now consider the effects of this general transformation in different policy areas.

\section{The Transformation of Public Policies: a Cross-Sectoral Analysis}

Of particular interest within the French context is the evolution of the role of the state. The strong control of public administration is often cited as the hallmark of French politics, and European integration seems to challenge this aspect of the decision-making process. How does the transformation of the political structure play out in the evolution of specific policy-making? Our selection of case-studies is centred on policy areas where European integration seemingly induced profound changes. By studying the evolution of monetary and fiscal policy, public service provision, agriculture and equal employment policy, we compare the different policy types of macro-economic stabilisation, distribution, redistribution and regulation. We do find four somewhat different patterns of Europeanisation from the mid-1980s until today. The impact of the EU on monetary and fiscal policy can be characterised as a tight constraint: While monetary policy competences have been transferred to the supranational level, fiscal competences are bound by the provisions of the Stability and Growth Pact, even though they remain at the national level. In the case of public services, competences are increasingly intertwined between delivery at the national level and regulation at the EU level. Agriculture turns out to be a highly integrated policy area with considerable competences transferred to European institutions, including redistribution. Equal employment, finally, is an area where the EU policy sphere has served as a political opportunity for the activism of domestic actors wanting to advance gender issues at the national level. 


\section{Monetary and Fiscal Policy}

There is little doubt that French monetary and fiscal policy radically changed in the last 20 years. Monetary policy-making has been transferred to the supranational level with the agreement to launch a single European currency and the creation of the European Central Bank. Fiscal policy has evolved in response to both international and European pressures, but the Economic and Monetary Union (EMU) criteria have the most visible and immediate effect on the room for manoeuvre of national decision-makers. Traditionally, French economic policymaking was characterised by strong state control, what Michel Gueldry identifies as a combination of Jacobinisme and dirigisme. ${ }^{14}$ Three overarching principles guided the relevant political process: centralisation of decision-making, the defence of national independence and fears of social dislocation. Monetary and fiscal policies were parts of a larger policy mix that aimed not only at managing state expenditures, but also at stimulating the economy in a Keynesian tradition. The exchange rate stability regime of the European Monetary System (EMS) ${ }^{15}$ as well as the liberalisation of financial markets since the mid-1980s put an end to this traditional pattern and forced France to develop a more credibility-oriented fiscal policy. Its main objective became to signal foreign investors that France could provide sustainable and sound economic conditions.

The ideological shift away from Keynesian economics happened with the "virage de la rigueur", the ideological "U-turn" of the Mitterrand government only two years after its election in 1981. As part of its economic programme, the new socialist government resorted to a budget deficit in order to provide an economic stimulus meant to boost domestic consumption and eventually to create new jobs. The deficit stimulated domestic demand in the short run, but had disastrous side-effects. It deteriorated current accounts, brought high inflation and finally led to three painful devaluations of the Franc in 1982-83. With a two-digit inflation rate, the French economy had to stabilise its monetary conditions and restore its external balances. This issue was all the more urgent, since France was part of the European Monetary System (EMS) at that time. Staying within the EMS implied stable exchange rates and, in the case of inflation, high interest rates. After heated debates within the French public and his own party, François Mitterrand finally decided on 21 March 1983 to undo his economic policy and to aim for a Franc fort. As a result, the use of fiscal policy as a discretionary instrument de-

The EMS existed since 1979 when major European economies agreed to set up a monetary system with semi-fixed parity to avoid exchange rate instability. This aim implied a convergence of monetary and indirectly fiscal policy. 
creased, having to abide by the EMS regime of stable exchange rates and, therefore, to the low inflation objective of the German Bundesbank.

The fiscal rigor adopted since 1983 was reinforced as a policy objective by the international integration of financial markets in the late 1980s. Starting with the "big bang" of the London stock exchange in 1986, most developed countries liberalised their financial markets. The liberalisation encompassed both the international integration of financial markets and the internal integration of the French domestic market, where capital was allowed to flow from the stock exchange to the bond market and to the futures markets. These in- and outflows of capital had an influence on the exchange rates as well as the long-term and short-term interest rates. To avoid being charged a hefty "risk premium" on its sovereign debt - which would have meant imposing high interest rates on its economy and destabilising its currency -, the French government had to demonstrate its willingness to curb public expenditures. Fiscal policy became a major instrument to gain credibility. In parallel, it also became a tool to increase the efficiency of the productive sector. This supply side policy encompassed cuts in capital taxation as well as in investment in infrastructures. The objective of this policy was to restore competitiveness within a fixed exchange rate regime, and was labelled "désinflation compétitive".

The EMS succeeded in assuring increasing monetary stability during the 1980s, but with considerable structural distortions between the participating countries, creating a painful asymmetry between the different currencies. Especially France and Italy suffered times of recession and growing unemployment. Among French politicians and the general public, there was an increasing sense that French monetary decisions were made by the German Bundesbank.

From the French perspective, EMU became a primary objective as an attempt to restrain German monetary power. ${ }^{16}$ Signed on 7 February 1992, the Maastricht Treaty laid the foundations for European monetary integration. It prepared the launch of the unified currency in several steps. After agreeing on EMU by ratifying the Maastricht Treaty, the participating countries started coordinating their monetary policy through a convergence programme on 1 January 1994. The European System of Central Banks would coordinate monetary policy within European countries, overseen at the time by the European Currency Institute which was in charge of making recommendation on disciplines to the candidate countries. The Euro was finally launched on 1 January 1999, and monetary policy is since then integrated at the level of the European Central Bank. 
The constraints of EMU on national fiscal policy-making are well-known: The Stability and Growth Pact signed by all adherents institutionalised the Maastricht criteria of a $3 \%$ limit on budget deficits, a gross government debt of less than $60 \%$ of GDP, and foresaw a system of financial penalties in case of breaching the agreement. Furthermore, governments were obliged to harmonise procedures for reporting data.

Even though the constraints of this regime are remarkably high, domestic fiscal policy paradoxically gained in importance. As the possibility of a nominal adjustment of exchange rates is now excluded, fiscal policy remains the major instrument that could ensure cyclical adjustment in the case of asymmetric shocks. The criteria of the Stability and Growth Pact aim at undermining such a use in the absence of balanced budgets. But French as well as German governments hardly meet sufficient rates of growth by the sole virtue of fiscal rigor. They also face domestic pressures to maintain public services and social welfare, and to lower the level of taxes. Budgetary deficit is, therefore, a tempting strategy for economic as well as political reasons. In 2003, both governments ended confronting the European Commission and other member states for by-passing the Stability Pact. However, they politically succeeded to force their way in that direction, with the Council refusing to back the penalties proposed by the Commission.

Compared to the early post-war period, when France was completely sovereign over its fiscal and budgetary decisions, the current EMU requirements do indeed seem like a "fiscal straitjacket". ${ }^{17}$ A major paradigmatic shift occurred in macroeconomic policy, as monetary policy is no longer used as an adjustment variable to fiscal policy, as it was previously the case. This policy change was not imposed by EU institutions to the French government, but it has been locked in through the independence of the ECB and the Stability Pact. Nevertheless, national governments remain more sensitive to domestic pressures than to EU sanctions, because they influence elections more directly and the penalty system is not fully deterrent. ${ }^{18}$ Governments are, therefore, likely to use or expand their rooms for manoeuvre with fiscal policy. Some even argue, as Roger Fauroux, that France would have never been able to make its recent budgetary decision under the EMS, where it would have led to a devaluation of the French currency. ${ }^{19}$ Compared to the fiscal rigor France had to abide by during the late 1980s, the Euro framework in some way seems to leave more autonomy to national fiscal decisions than before, despite the $3 \%$ deficit ceiling. 
To summarise the transformation of monetary and fiscal policy in France, one must acknowledge the profound changes that have happened in the course of international and European integration. France has given away control over important aspects of economic policy-making, but has done so very strategically. The Franco-German relation was crucial in these developments. The constraints on national fiscal policy-making were seen as the price to pay for the desired monetary integration that permitted to "control" the power of the German Bundesbank. The idea of sharing sovereignty over the single currency was repeatedly advanced by supporters of European integration. But the argument was largely rhetoric, as decision-making regarding the Euro is very remote from the anterior relations between French governments and the Banque de France, and indeed out of reach of the Council. In fact, from a Jacobin point of view, the Euro is a joint renunciation to sovereignty over the currency. What remains under the influence of the executive in macro-economic policy is indeed fiscal policy and its co-ordination. The joint pressure of France and Germany to re-negotiate the conditions of the Stability and Growth Pact surely needs to be understood in that way. Although the French economy is no longer centrally planned in Paris, ${ }^{20}$ this does not mean that the government has no room for manoeuvre in the European arena. Moreover, these economic policy changes resulted primarily from national adjustments and remain "path dependent". ${ }^{21}$ Within the constraints imposed by European monetary integration and international financial markets, French economic policy has become "the art of the possible" 22 , or a peculiar form of "market-oriented dirigisme".

\section{Public Services}

More than any other policy area, public services in France represent the model of state-society relations characterising the prevalent pattern of governance under the Fifth Republic. ${ }^{23}$ The challenges posed to the provision of public services are, therefore, emblematic of the tensions between European decision-making and the French notion of state power, a well-constructed balance between the discretion of the state and its elites and direct democracy. ${ }^{24}$

20 The decline of national industrial policy, in line with the competition policy of the single market, equally contributes to the retreat of the state in the economy.

21 Schmidt, V.A.: Europeanization and the Mechanics of Economic Policy Adjustment, in: European Integration online Papers, 5/6 (2001), 1.

22 Gueldry, M. R., op. cit., 85.

23 Cole, A./Drake, H., op. cit., 30.

24 Rouban, L.: La réforme de l'Etat en Europe: quel avenir pour le service public?, in: d'Arcy, F./Rouban, L. (eds.), op. cit., 143-162, here 144 . 
The French conception of public services is firmly rooted in a combination of Republican values, the legacy of Colbertism and the structure of the fonction publique along the lines of corps. ${ }^{25}$ In France, public services include the state provision of health, social assistance, social security and education as well as a high degree of state interventionism in industrial policy, most importantly the provision of so-called natural monopolies or infrastructure services: gas, electricity, transport and communication services. The priority for the state's role in these services is enshrined in the preamble of the 1946 Constitution stating that "all good, all business, of which the exploitation acquires the characteristics of a national public service or a monopoly de fait must be collectively owned". Employment in the state-owned gas, telecom or transport enterprises consequentially benefited from the protection of the fonction publique. The obligation to serve the public interest, furthermore, imposed several constraints on the operation of these firms: A public utility firm had to charge the same fees to all consumers independent of costs and was not allowed to make any profit, so that they would not abuse their public sector monopoly. In return, these firms had many privileges provided by law, which shielded them from the rigors of full competition.

European integration started to pose serious challenges to the French model of public services during the late 1980s and the 1990s. Before the Single European Act (SEA) of 1986, the European Community had largely left public services untouched. Pressures for change were a direct consequence of the single market project, and most immediately from the Competition Directorate and individual commissioners, such as Leon Brittan and Karel van Miert. The single market programme gave the Commission a large legal base to issue directives concerning specific sectors. In this context, the French conception of public service was considered in direct conflict with EU competition policy, which upheld that European firms should be able to compete with each other on equal terms. This challenged the involvement and subsidies of the state in many sectors and questioned the tradition of sometimes loss-making public services and France's grands projets. ${ }^{26}$

The French response to pressures for change coming from the EU was twofold. To a certain degree, the European framework sometimes functioned as a welcome smoke screen for the modernisation of the public sector and institutionalised a new political approach to public services provision. ${ }^{27}$ In other aspects, however, in Britain and France, Oxford, 1999.
Cole, A.: The 'service public' under Stress, in: West European Politics, 22/4 (1999), 166-184.

These grands projets are not only typical of the heroic French industrial policy style, but rather a part of the French national identity. The fact that many of these achievements - the Concorde, satellites, railways or sea transport - are reprinted on the pages of French passports testifies to this.

Cf. Thatcher, M.: The Politics of Telecommunications: National Institutions, Convergence, and Change 
the French government showed a considerable amount of determination not to follow Margaret Thatcher's road to deregulation. Some of the Commission's earliest victories were the opening up of the European air transport market by 1 April 1997 and of the European telecommunication infrastructures on 1 January 1998. The deregulation of the energy sector, in turn, was met with more resistance. The French government first delayed the implementation of the Commission's 1996 directive to 1999 and then only implemented the minimum standard. Defending the state-owned company EDF-GDF was clearly a major priority for the French government, and the politically sensitive re-organisation of the firm was delayed until 2004.

European influence was not limited to direct implementation of EU directives. It also resulted in changing policy fashions. Public services reform has to be understood in a more general trend towards privatisation. Since World War II, the French state had led efforts towards investment and reconstruction, with a first wave of nationalisation in 1946. After this early programme, the state owned large portions of the industry, notably in the sectors of transport, automobile, steel and energy. The Mitterrand government's nationalisation programme of 1981-82 added some leading industrial groups and a large part of the financial sector to the state's assortment. Starting in 1986, the government has undertaken the privatisation of firms, not only to undo the decisions made in 1981, but also to reform and modernise those enterprises nationalised in 1946. Typical for French industrial policy, privatisation did not necessarily mean a retreat of the state, which most often preserved a powerful oversight role - if not though direct ownership then through the selection of shareholders close to the state's economic interests. ${ }^{28}$

The pervasiveness of this policy change became clearer under the government of Lionel Jospin who took office in June 1997. The left had long resisted privatisation in any form. During the years 1988-93, industrial policy had been determined by Mitterrand 's "ni-ni" doctrine, "neither nationalisation, nor privatisation". Even in the 1997 party manifesto, the French socialists pledged to stop the privatisation that had been undertaken until then. However, the Jospin government proved to be less categorical and more pragmatic, and assorted its decision on the interest of firms on a case to case basis. It is true that the cases of GAN-CIC and Crédit Lyonnais were a consequence of EU competition law, but the partial privatisations of firms, such as France Télécom, Thomson-Alcatel or Aerospatial-Matra, were undertaken to allow for international alliances and consolidation in the respective industries. 
Since 1982, French authorities have privatised about 2,000 firms, resulting in a decline in employment through state-owned enterprises by 1.35 million. ${ }^{29}$ Nevertheless, the state remains a central actor in the French economy, still owning some 1,500 enterprises in 2000, most of them of small or medium size. Only 97 companies are directly owned by the state, the remainder being controlled indirectly. Among the six most important former public service companies - Air France, France Telecom, La Poste, EDF/GDF, RATP and SNCF - only the first two have been partially privatised. ${ }^{30}$ While critics still insist on the former public service elements that continue to be under tight state control, the transformation of the sector has been considerable. The general framework for evaluating public service provision turns out to be more market-oriented, inspired by the guidelines of the EU, and international and European partners continue to press for further privatisation of former state monopolies. However, the application of these requirements has so far been a quite interesting mix of state-led market orientation and the preservation of "core" public services. In 1997, even the Amsterdam Treaty acknowledged the existence of "general interest services", demonstrating the determination of the government to defend French-style policy-making after the protest movement of 1995. The Treaty, furthermore, allowed for state aids to specific public service missions under Article 90-92 of the Treaty of Rome.

Although France considerably revised its own policy approach in line with EU competition law, the core of public services provision and values has been preserved, and continues to influence policy decisions, even within very "Europeanised" circles of the French civil service. ${ }^{31}$ French privatisation did not induce a full retreat of the state from the economy. Most importantly, the state maintained covert control over firms through cross-shareholdings. Despite the radical changes that public services have undergone to face deregulation in some sectors, they are still torn between the alleged requirements of international competitiveness and Republican values. ${ }^{32}$

While the employment in state-owned firms has been declining due to privatisation, the percentage of the public sector employment has consistently increased. While only 20 percent of the French working population was employed by the state in 1980, the percentage has risen to over 25 percent in 2000 . See OECD: Economic Survey - France, Paris, 2003. OECD, op. cit., 87.

Rouban, L.: Les cadres du privé et du public: des valeurs sociopolitiques en évolution, in: Revue Française d'Administration Publique, 98 (1998), 329-344; idem: La culture politique du secteur public: les chemins de l'utilitarisme, in: Bréchon, P./Laurent, A./Perrineau, P. (eds.): Les cultures politiques des Français, Paris, 2000, 241-258.

32 Cf. Rouban, L. (ed.): Le service public en devenir, Paris, 2000. 


\section{Agriculture}

Agriculture has long played an important role in French economy, politics and identity, but is, nonetheless, one of the most integrated domains of EU policymaking through the framework of the Common Agricultural Policy (CAP). In the early post-war period, the agricultural sector accounted for about 22 percent of French employment. ${ }^{33}$ When the number of farms and the importance of the sector started declining, the state intervened and granted a considerable amount of aide and subsidies. However, the condition for this support was a policy of modernisation which started with two "Lois d'orientation agricole" of 1960 and 1962, who have now almost gained mythical status. In particular, the state sought to increase productivity and efficiency of family farming, while encouraging producers unable to adapt to the internationalisation of French agriculture to leave the land. In many respects, the agricultural reform corresponded to the traditional national model of state-led planning, but with one important difference. In preparation of further policy development and the lessening of social tensions, the state constructed a bipartite corporatist system and delegated important responsibilities to the selected farm groups. ${ }^{34}$

Starting in the 1980s, several challenges emerged to put pressure on this policy approach. Coming from both above and below, the current crisis of the French agricultural policy is twofold. At the international level, trade negotiations in the framework of the GATT during the Uruguay Round and later in the World Trade Organisation increasingly put the CAP into question. Major exporting countries led by the US pushed for liberalisation, while the EU has so far resisted abandoning its subsidies due to French insistence. But even within the Union, the considerable costs of the CAP increased the pressures for reform. Sometimes referred to as the "welfare state for farmers", the CAP is by far the largest part of the EU budget, accounting for almost half of EU expenditures. ${ }^{35}$ Independently from the CAP reform, French agricultural policy, furthermore, was questioned domestically. Traditionally, the agricultural sector had been perceived as the production of food supply, but increasingly, agriculture seemed to relate to regional policies, the environment and territorial relations as well. The re-definition of the sector contributed to putting both professional organisations as well as public officials 
on the defensive. Eventually, the search for a new approach led to the Loi de modernisation de l'agriculture in 1995 and culminated in the creation of a new measure, called Contrats Territoriaux d'Exploitation (CTE) through another Loi d'orientation agricole in $1999 .{ }^{36}$

Coleman and Chiasson characterise the steps leading up to the 1999 law as "adjustment on its own terms: France's response to market liberalism". ${ }^{77}$ Indeed, agricultural reform was emblematic of a specific state-led market liberalism, similar to the "market-oriented dirigisme" cited in the context of fiscal policy transformation. The Loi d'orientation agricole of 1980 had made a first step towards identifying the role of the French agricultural sector in the world market and reforming the bipartite corporatist system established in the 1960s. In 1987, the government decided to privatise Crédit Agricole, the agricultural bank that had supported and directed the whole financing of the 1960 and 1962 policies. The Loi de modernisation de l'agriculture of 1995 eventually institutionalised a more open multipartite, vertical corporatist policy network by replacing various departmental committees with a single departmental commission, and including new representatives from professions adjacent to the agricultural sector.

Halfway through this transformation, it became clear that another important challenge to the old corporatist system came from the farming sector itself. ${ }^{38}$ Tensions developed within the dominant peak association, the Fédération Nationale des Syndicats d'Exploitants Agricoles (FNSEA), between supporters and opponents of the newer liberal approach to agriculture. It would soon be challenged by an opposition from the left, the Confédération Paysanne led by Jose Bove, which gained public media attention throughout the 1990s. During the preparation of the 1999 law, the government consulted more widely than it had done before. French agricultural policy today is arguably structured around more open "multipartite corporatism organized along commodity lines" 39 and has integrated the multidimensional role assigned to the sector. The principal tool of the 1999 law, the CTE, proposes to distribute financial assistance to farmers who are willing to develop a plan addressing together the economic, social and environmental functions of agriculture.

Even though this policy tool might mark a turn towards regulation, these contractual relations are not a purely economical, given the objectives they seek to

36 Muller, P.: La politique agricole française: l'Etat et les organisation professionnelles, in: Economie rurale, 255-256 (2000), 33-39.

37 Coleman, W. D./Chiasson, C., op. cit., 175.

38 Fouilleux, E.: La PAC et ses réformes: une politique à l'épreuve de la globalisation, Paris, 2003; Delorme, H.: Les syndicats agricoles français et la répartition des aides publiques: contexte et contenu du débat, in: Economie rurale, 233 (1996), 49-54.

39 Coleman, W.D./Chiasson, C., op. cit., 169. 
address. The 1999 law redefined the French agricultural sector and instituted a market-oriented policy that was nonetheless state-led. In line with the CAP reform, the introduction of the CTE, furthermore, reduced the distributive nature of national agricultural policy by focusing aids on specific target groups, thus making it more redistributive. The most important determinant of French agricultural policy remains the framework dictated by the European policy direction. In a way, the turn towards a more inclusive consultation with a large variety of producers and consumers' interests might be understood as a way for the French state to increase a sense of pluralism in agricultural governance. Through mediaeffective protests and its relevance for a large part of the euro-sceptic rural population, the agricultural question has also become the prism through which the issues of both domestic and European governance receive public attention. Issues such as food-safety, genetically modified organisms, world trade and subsidies to farmers indeed jointly question national and EU public policy, and have become a matter of public concern. The transformation of the French agricultural policy is, therefore, not only a sectoral issue, but broadly affects the attitudes of French public opinion towards the EU. Interestingly, while France was at the initiative of the CAP in the early 1960s, has the larger share of exports in the sector, and is the main recipient of its subsidies, it also hosts most of farmers' social movements contesting EU policy. This may be explained by the large number of French farmers being dependant on the CAP and affected by its reform. In sum, this case study reveals that the national and European levels of public policy are extremely integrated and that the CAP has an important impact on domestic politics in France.

\section{Equal Employment Policy}

As part of a larger framework of gender politics, equal employment policy is a domain where the national and the European levels are intertwined. ${ }^{40}$ France has played a quite active role in the formulation of EU policy initiatives, in some cases in order to circumvent opposition at the national level, and so equal employment policies developed in parallel and in response to EU directives.

Government regulation of women's position in the work force has evolved during the last century from protection of mothers to the development of a

40 In most European countries, the label "equal employment policy" refers implicitly to gender-based equality at work alone. Race-based employment, which is often included in US equality debates, tends to be treated in different policy contexts, such as immigration. 
comprehensive and proactive policy aiming at assuring equal pay and treatment of female work. This new policy orientation, managed by an array of women's policy offices has been labelled "state feminism" and is considered the hallmark of the French case. ${ }^{41}$ Dating back to 1892 and 1909, early policy acts included special protection for women through the restriction of working time or the prohibition of night work and the introduction of a maternity leave.

Starting in the 1960 s with the extension of women's employment as wageearners, a political, legal and cognitive shift occurred. The Mouvement Démocratique Féminin, created in 1962 by Yvette Roudy and Colette Audry, began to insist on a re-definition of women's rights in terms of general citizenship rights and not only as a consequence of their family roles. Based on the 1946 Constitution, which had enshrined the principle of equality between men and women, the movement started targeting issues related to the specific situation of women's economic activities. In 1946, a decree had abolished lower pay rates for women, and collective agreements in 1950 extended the decree to equal pay. However, there was little agreement as to what these principles would have to apply to. Established in 1966, the Comité du Travail Féminin (CTF) was a major actor in promoting equality and an important locus for French policy development on the issue, publishing a number of studies on the situation of woman in the work force in the 1960s and early 1970s. A law in 1972 specified that equal pay should apply to "work for equal value", while another law of July 1975 started tackling issues around the hiring and firing of individuals based on gender motivations. Yet the most important improvement came only in 1983, with a law named after the Minister of Women's Rights of the Mitterrand government, Yvette Roudy. This law implemented the idea of "equal work", improved the 1975 law, and integrated equality concerns in a more general framework of employment conditions and cooperation between social partners. In 1987, the French government took a more active role in employment relations by establishing "le contrat pour la mixité des emplois", which provided firms with the possibility to obtain state subsidies for hiring and training female employers. Finally, a 2001 law reinforced several provisions of the 1983 law and made employment equality a major element of collective bargaining agreements. Despite this concerted legislative effort, the implementation of these equality provisions remains symbolic rather than concrete, due to limited support for positive action strategies among French firms and unions. ${ }^{42}$

Levy, M.: Le féminisme d'état en France 1965-1985, doctorat en sciences politiques, Paris, 1988; Mazur, A.G. (ed.): State Feminism, Women's Movements, and Job Training, New York, 2001; Laufer, J.: Equal Employment Policy in France: Symbolic Support and a Mixed Record, in: Review of Policy Research, 20/3 (2003), 423-442, here 425.

42 Laufer, J., op. cit., $423 \mathrm{ff}$. 
Following the Comité du Travail Féminin, the different study groups and the growing French feminist movement contributed to the evolution of the issue both nationally and at the European level. Even before the 1960s, France has often played a pioneering role in bringing EU gender policy forward. Article 119 on equal pay and work in the Treaty of Rome of 1957, for example, was a French initiative, although it was introduced in the context of equal competition between member states. ${ }^{43}$ Operating as experts or consultants on women's issues - socalled "femocrats" -, French feminists have later continued to play instrumental roles in the development of EU equal employment policy, often as a means to advance a feminist agenda in reluctant French policy circles. ${ }^{44}$ The most important EU measures include the Directives on Equal Pay ${ }^{45}$, Equal Treatment ${ }^{46}$ and the Recommendation on Positive Actions ${ }^{47}$, and established equal employment as a principal focus of early EU gender policy. The Amsterdam Treaty (Art. 141 TEC-A) and a series of ECJ decisions on positive action ${ }^{48}$ reinforced the European framework. Through Article 3 (2) TEC-A, the EU furthermore institutionalised the notion of "gender mainstreaming", a policy framework asserting that gender equality must be integrated in definition, formulation, and implementation of policies and agreements in all policy fields. ${ }^{49}$

The exact impact of European gender policy on French equal employment measures is difficult to disentangle. The specific effects of EU and national legislation are not easy to sort out, while implementation at the firm level remains difficult to assess. Early studies of the Europeanisation of gender politics tended to concentrate on the adaptive pressures posed by the European framework and

43 Hantrais, L.: From Equal Pay to Reconciliation of Employment and Family Life, in: idem (ed.): Gendered Policies in Europe, London, 2000, 1-26.

44 Bereni, L.: Le mouvement français pour la parité et l'Europe., in: Jacquot, S./Woll, C. (eds.): Les usages de l'Europe, Paris, 2004, 33-54.

45 Council Directive 75/117/EEC of 10.02.1975 on the Approximation of the Laws of the Member States Relating to the Application of the Principle of Equal Pay for Men and Women (Official Journal no. L 045/19 of 19.02.1975).

46 Council Directive 76/207/EEC of 09. 02.1976 on the Implementation of the Principle of Equal Treatment for Men and Women as Regards Access to Employment, Vocational Training and Promotion, and Working Conditions (Official Journal no. L 039/40 of 14. 02.1976).

47 Council Recommendation 84/635/EEC of 13.12.1984 on the Promotion of Positive Action for Women (Official Journal no. L 331/34 of 19.12.1984).

48 ECJ, judgement of 17.10.1995, case C-450/93 (Eckhard Kalanke/Freie Hansestadt Bremen), rec. 1995 I, 3051; ECJ, judgement of 11.11.1997, case C-409/95 (Hellmut Marschall/Land Nordrhein-Wetsfalen), rec. 1997 I, 6363; ECJ, judgement of 28. 03. 2000, case C-158/97 (Georg Badeck et al.), rec. 2000 I, 1857.

49 Pollack, M.A./Hafner-Burton, E.: Mainstreaming Gender in the European Union, in: Journal of European Public Policy, 7/3 (2000), 432-456; Jacquot, S.: Sequences of Policy Change: European Gender Equality Policies and the Advent of the Gender Mainstreaming Principle, 1989-1996, Paper presented at the ECPR General Conference, Marburg, 2003. 
to stress poor implementation at the member-state level. ${ }^{50}$ From a comparative perspective, the "misfit" between the European and the national levels as well as the domestic "needle eye" that EU policy had to pass through play an important role in explaining the lack of convergence of European gender policies. ${ }^{51}$ Yet, as Ulrike Liebert points out, European governance in areas of positive integration, such as social and employment policy, does not only rely on hierarchical mechanisms, but rests on a wide range of "soft mechanisms" that are based on knowledge, social learning and "best practices". ${ }^{52}$ Furthermore, and especially in the case of France, the European integration of gender policy was shaped by national impulses, where the EU serves as an area for feminist movements to express their demands. ${ }^{53}$ But the reverse is equally true: French initiatives were quite often inspired by European developments. Before becoming Minister for Women's Rights in 1981, Yvette Roudy, for example, was a Member of the European Parliament. In her own accounts, she found there the most important inspiration for the 1983 French law. As both Sonia Mazey and Laure Bereni underline, ${ }^{54}$ the European policy domain is as much an extension of French policy objectives as it was a welcome constraint on traditional French employment policies. The relationship between French and European policy developments in the field of equal employment should, therefore, be considered as a mutually reinforcing one.

\section{Patterns of Policy Adaptation}

The review of these four sectors makes clear that even in the most integrated policy areas the EU did not simply supplant French policy-making. Nonetheless, the role of European integration in designing new opportunities and constraints for public policy is very apparent. The EU presents a severe, yet self-imposed con-

Ostner, I./Lewis, J.: Gender and Social Policy, in: Leibfried, S./Pierson, P. (eds.): European Social Policy, Washington, D. C., 1995, 159-193; Caporaso, J./Jupille, J.: The Europeanization of Gender Equality Policy and Domestic Structural Change, in: Caporaso, J./Green Cowles, M./Risse, T. (eds.), op. cit., 21-43.

51 Ostner, I./Lewis, J., op. cit., 161.

52 Liebert, U.: Europeanization and the "Needle's Eye": the Transformation of Employment Policy in Germany, in: Review of Economic Studies, 20/3 (2003), 479-492; Liebert, U./Sifft, S. (eds.): Gendering Europeanization, Brussels, 2003.

53 Cichowski, R.: "No Discrimination Whatsoever": Women's Transnational Activism and the Evolution of EU Sex Equality Policy, in: Naples, N. A./Desai, M. (eds.): Women’s Activism and Globalization, New York, 220-238.

54 Mazey, S.: L'Union européenne et les droits des femmes: de l'européanisation des agendas nationaux à la nationalisation d'un agenda européen?, in: Balme, R./Chabanet, D./Wright, V. (eds.): L'action collective en Europe, Paris, 2002, 405-432; Bereni, L.: Le mouvement français pour la parité et l'Europe, in: Jacquot, S./Woll, C. (eds.), op. cit., 33-54. 
straint on monetary and fiscal policy. While monetary policy is now integrated at the supranational level, fiscal policy has mainly evolved from an instrument of cyclical readjustment to a signal for financial credibility. Nevertheless, fiscal policy is still used, within certain margins, as an adaptive strategy to monetary stability. As regards public services, the French government had to re-define its purely distributive approach when it was conflicting with EU competition law. Public service provision continues to be state-led in important sectors like transportation, education and health, but is overall much more market-oriented. Compared to macro-economic policy, governments have been more reactive than proactive on this issue. They negotiated to delay implementation in some areas, such as energy, and to include a provision on public services in the Amsterdam Treaty. Policy change in agriculture underwent a rather similar reactive pattern of transformation since the 1990s. However, the re-definition of agriculture did not only respond to the requirements of international trade negotiations, but also to the new cleavage structure of non-governmental actors and public opinion, progressively questioning the productivity orientation of agriculture. Top-down European pressures only contributed to a more general re-definition of the sector. Finally, equal employment policy co-evolved at the national and European levels. A more recent issue with fewer implications for state sovereignty, gender issues illustrate well how the EU can serve the advancement of issues traditionally ne-

Table 1: Adaptation to European Integration in France: Four Policy Areas Compared

\begin{tabular}{|l|l|l|l|l|}
\hline & Monetary/Fiscal & Public Services & Agriculture & $\begin{array}{l}\text { Equal } \\
\text { Employment }\end{array}$ \\
\hline Policy Type & $\begin{array}{l}\text { Macro-economic } \\
\text { stabilisation }\end{array}$ & Distributive & Redistributive & Regulative \\
\hline $\begin{array}{l}\text { Period of } \\
\text { major changes }\end{array}$ & $1983-1999$ & $1997-$ present & $1993-1999$ & $1983-2001$ \\
\hline $\begin{array}{l}\text { Degree of } \\
\text { change }\end{array}$ & High & Medium & High & Medium \\
\hline Main effect & $\begin{array}{l}\text { Lock-in of } \\
\text { monetarism }\end{array}$ & $\begin{array}{l}\text { Privatisation, } \\
\text { market provision } \\
\text { (limited) }\end{array}$ & $\begin{array}{l}\text { More selective } \\
\text { criteria for } \\
\text { allocation }\end{array}$ & $\begin{array}{l}\text { Normative } \\
\text { co-evolution }\end{array}$ \\
\hline $\begin{array}{l}\text { Adaptation } \\
\text { strategy }\end{array}$ & $\begin{array}{l}\text { By-passing the } \\
\text { Stability Pact }\end{array}$ & $\begin{array}{l}\text { Delaying } \\
\text { implementation } \\
\text { EU Agenda- } \\
\text { setting }\end{array}$ & $\begin{array}{l}\text { Resisting the } \\
\text { CAP reform in } \\
\text { EU bargains }\end{array}$ & $\begin{array}{l}\text { Agenda-setting } \\
\text { at EU level }\end{array}$ \\
\hline
\end{tabular}

Source: Authors' compilation. 
glected in French policy-making. In this area, the EU is clearly more an opportunity than a constraint for policy development at the domestic level. Nevertheless, even though the regulatory approach of gender policy is quite in phase with the general style of European policy-making, such a compatibility does not imply that policy has been implemented more easily than in other sectors. On the contrary, despite the overall fit between French and European legislation, the dispersion of interests involved with equal employment policies across countries and sectors explain why measures undertaken are generally criticised as not being effective. These findings are summarised in Table 1.

\section{Conclusion}

Our analysis has tried to identify patterns of changes within French policy-making associated with European integration. The findings confirm at a very general level a trend toward less direct state involvement in policy-making, compared to the peak of French dirigisme of the early 1980s. Yet, the degree to which the French state remains at the centre of new policy developments is quite striking. Distributive policies forming the core of the welfare-state did not significantly regress. While under severe pressure to transform due to their high budget intensity, they are also resistant to changes because of well-organised vested interest groups defending the status quo. One may simply recall to the vigorous protest movement in 1995 or the more recent difficulties of the Raffarin government in reforming the pensions systems. As a consequence, the bulk of distributive policies so far followed more incremental than radical changes. More generally speaking, it seems that distributive policies tend to evolve towards more specifically targeted redistributive policies, which are more in line with the structure and design of EU policies. Furthermore, regulative policy domains, even if less exposed to tensions in policy styles at the national and supranational levels, are not necessarily the most transformative. Quite cynically, despite the greater role of the EU in equal employment policy, new regulations have limited actual effects at the domestic level. The development of regulation can also be linked to a deficit of public policy implementation.

Europeanisation, therefore, does not simply equate to a standardisation of public policy based on the extension of regulation as a policy instrument. Patterns of policy changes are highly complex and diversified, and their "path-dependency" is rooted in the political feasibility of public policy at the domestic level. In a way, monetary policy was easy to transfer at the EU level, because governance is more state-centred than in other policy areas. Distributive and redis- 
tributive policies are more politically sensitive, due to their social implications, and because of interest groups acting as veto players in many sectors. Through agenda-setting as well as implementation, governments, therefore, use adaptive strategies to moderate or accommodate the domestic impact of EU policies. Finally, regulative policies are in a way easy to abide with, as long as their implementation is left to judicial action. The European "regulatory state", in many areas, remains a weak one.

Nevertheless, the effects of the EU on French policy-making are quite visible. Our conclusion suggests that regulative and redistributive policies are less conflicting with European integration than distributive policies at the core of the French version of welfare state, but that the latter are also strongly resilient and resistant to radical changes. Changes equated with the "tournant néo-libéral" in France ${ }^{55}$ have been contained and are not exclusively market-orientated, as our case studies have illustrated. A large number of distributive policies persist and continue to address social concerns. The French state continues to have a strong role in framing, conditioning and balancing the market through active and direct regulation.

55 Jobert, B.: Le tournant néo-libéral en Europe: idées et recettes dans les pratiques gouvernementales, Paris, 1994. 